\title{
PENINGKATAN PENGETAHUAN DAN PERUBAHAN SIKAP TERHADAP PENGOLAHAN MINYAK JELANTAH MENJADI SABUN (SABUN MIJE)
}

\author{
Yusnita $^{1^{*}}$, Syukrini Bahri ${ }^{2}$, Insan Sosiawan A Tunru ${ }^{3}$ \\ I Bagian Ilmu Kedokteran Komunitas, Fakultas Kedokteran, Univeristas YARSI, Jakarta, Indonesia \\ ${ }^{2}$ Bagian Ilmu Patologi Klinik, Fakultas Kedokteran, Univeristas YARSI, Jakarta, Indonesia

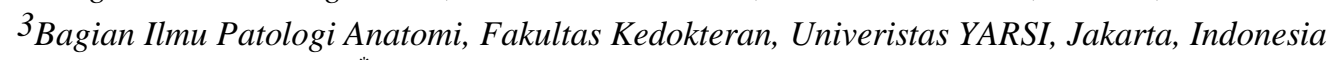 \\ *Penulis Korespondensi: yusnita@yarsi.ac.id
}

\begin{abstract}
Abstrak
Food safety atau keamanan pangan merupakan kondisi dan upaya yang diperlukan untuk mencegah pangan dari kemungkinan kerusakan akibat cemaran biologis, kimia dan fisika. Kerusakan kimia pada makanan dapat terjadi dengan pemakaian berulang minyak jelantah yang menimbulkan efek negative bagi kesehatan dan jika dibuang dapat mencemari lingkungan. Kegiatan pengabdian masyarakat ini bertujuan membuat materi dan memberikan pelatihan untuk meningkatkan pengetahuan dan sikap pengolahan minyak jelantah menjadi sabun (sabun mije). Metode yang dilakukan pada kegiatan ini adalah penyusunan materi dan pelatihan pembuatan sabun mije. Materi panduan yang disusun berupa bahan presentasi dengan PPT, leaflet dan video demonstrasi. Sebelum dan setelah pelatihan diukur pengetahuan dan sikap peserta dengan kuesioner. Data hasil kuesioner akan dianalisis univariate untuk melihat karakteristik responden dan bivariate dengan uji t berpasanagn untuk menilai peningkatan pengetahuan dan uji Mc nemar untuk menilai perubahan sikap. Kegiatan pelatihan dilakukan di (RPTRA) Harapan Mulia, Kemayoran Jakarta Pusat dengan diikuti 20 peserta. Pengetahuan peserta sebelum dan sesudah pelatihan meningkat dari rata-rata 46,25 menjadi $72,65(\mathrm{p}=0,000)$. Perubahan sikap juga terjadi dimana sebelum pelatihan sikap positif sebanyak $45 \%$ menjadi $85 \%$ setelah pelatihan $(\mathrm{p}=0,031)$. Peningkatan pengetahuan dan sikap yang significan ini diharapkan dapat meningkat peningkatan perilaku yang baik dalam pengolahan limbah minyak jelantah.
\end{abstract}

Kata Kunci: Pengolahan limbah; pengetahuan; sikap; minyak jelantah; sabun mije.

\begin{abstract}
The use of used cooking oil for cooking can cause negative effects for health. The used cooking oil when disposed can pollute the environment. This community service aims to create materials and provide training for the enhancement of the knowledge and attitude of the processing of used cooking oil to soap. The methods performed on this activity are training of soap making. This activity was done Kelurahan Harapan Mulia, Kemayoran, central Jakarta with the target of 20 housewives. The guide material is composed of presentation materials with PPT, leaflets and video demonstrations. Before and after training measured participants knowledge and attitudes with the questionnaire. The Data analyzed univariate to see the characteristics of respondents and bivariate with a postwar test to assess the increase in knowledge and test Mc Nemar to assess the change in attitudes. There were increasing knowledge from an average of 46.25 to $72.65(P=0,000)$. Attitude changes also occurred before the training of positive attitudes as much as $45 \%$ to $85 \%$ after training $(P=0,031)$. The increased knowledge and attitudes that are statistic significan are expected to increase the increase in good behaviour in the processing of household waste, especially processing the waste oil.
\end{abstract}

Keywords: Sewage treatment; knowledge; attitude; cooking oil.

\section{PENDAHULUAN}

Undang-undang RI No. 18 tahun 2012 tentang Pangan (UU Pangan) disebutkan bahwa pangan yang aman adalah bahan pangan yang terhindar dari cemaran biologis, kimia dan benda lain yang mengganggu, merugikan dan membahayakan kesehatan manusia. 
Karena makanan merupakan kebutuhan dasar manusia jadi keamanan pangan harus terjamin, dari pangan yang terpenting adalah keamanan pangan. Supaya makanan bisa memberikan manfaat yang maksimal maka makanan tersebut harus beragam, bergizi, seimbang dan aman. Jadi makanan tersebut harus memenuhi empat konsep B2SA (Beragam, Bergizi, Seimbang dan Aman) (UU No.18 tahun 2012 tentang Pangan).

Perilaku terhadap makanan adalah respon seseoramg terhadap makanan sebagai kebutuhan vital bagi kehidupan. Unsur-unsur yang terkandung didalamnya zat gizi, pengolahan makanan, dsb. Food safety atau keamanan pangan merupakan kondisi dan upaya yang diperlukan untuk mencegah pangan dari kemungkinan kerusakan akibat cemaran biologis, kimia dan fisika (UU No.18 tahun 2012 tentang Pangan).

Penelitian tentang food safety lebih banyak ditemukan pada industri makanan baik pengolahan makanan di pabrik maupun pengolahan makanan di industri kuliner baik di hotel, restaurant maupun penjaja makanan namun fokus food safety diu rumah tangga masih sangat kurang. Untuk itu telah dilakukan kegiatan pengabdian kepada masyarat verupa penyuluhan tentang food safety di rumah tangga di keluahan harapan mulia. Hasil kegiatan tersebut menunjukkan pengetahuan ibu rumah tangga tenatng food safety adalah cukup dan pengetahuan meningkat menjadi baik setelah penyuluhan (Yusnita dkk, 2017). Dari 5 item pengetahuan tentang food safety yaitu pengetahuan mengenai zat pengawet pada daging dan ikan pengetahuan mengenai bakteri patogen, pengetahuan mengenai zat kimia berbahaya pada makanan, pengetahuan mengenai higienitas peralatan memasak dan pengetahuan mengenai zat pengawet pada tahu, pengetahuan yang paling rendah adalah pengetahuan tentang cara menjaga hiegienitas peralatan memasak Butir penyataan yang salah tentang penggunaan sabun dalam membersihkan peralatan memasak (Yusnita dkk, 2017).

Minyak goreng merupakan salah satu bahan yang banyak digunakan untuk kehidupan sehari-hari. Perkembangan industri kuliner menyebabkan dihasilkannya minyak goreng bekas dalam jumlah yang cukup banyak. Minyak goreng bekas ini atau dikenal sebagai minyak jelantah apabila dikonsumsi dapat mengganggu kesehatan. Minyak goreng bekas tersebut apabila dibuang dapat mencemari lingkungan. Untuk mengatasi hal tersebut minyak goreng bekas dapat dimanfaatkan kembali, salah satunya dengan mengubahnya menjadi produk sabun cuci piring cair. Sebelum diolah menjadi sabun, minyak goreng bekas dimurnikan terlebih dahulu. Pemurnian terdiri dari tiga tahap, yaitu penghilangan kotoran (despicing), netralisasi dan pemucatan (bleaching) (Pratiwi, 2014; Alfrozi dkk,2017).

Minyak goreng bekas atau minyak jelantah merupakan salah satu limbah rumah tangga yang cukup banyak dihasilkan. Hasil penelitian Vanessa dan Bouta didapat jumlah rata -rata enggunaan minyak goreng masyarakat Jabodetabek setiap kepala keluarga per minggunya adalah \pm 1 liter; Harapan Mulya adalah salah satu kelurahan yang terletak di wilayah Kecamatan Kemayoran, Jakarta Pusat. Kelurahan ini memiliki jumlah penduduk sebesar 23.130 jiwa dan luas wilayah $0,91 \mathrm{~km} 2$ yang terbagi dalam 6320 Keluarga (KK), 121 RT, 9 RW. Limbah minyak jelantah di Kelurahan Harapan Mulia sekitar 6.320 liter per minggu atau 25.280 liter bulan. Hasil evaluasi survey pada ibu-ibu kader PKK kelurahan Harapan Mulia menunjukkan bahwa belum pernah ada pelatihan pembuatan sabun dari minyak jelantah. Pemanfaatan minyak jelantah menajdi sabun cuci piring dapat menjadi solusi untuk pemanfaatan limbah cair rumah tangga dan peningkatan higienitas peralatan memasak di Kelurahan Harapan Mulia, kecamatan Kemayoran, Jakarta Pusat (Vanessa \& Bouta,2016).

\section{BAHAN DAN METODE}

Metode yang dilakukan pada kegiatan ini adalah penyusunan panduan dan pelatihan praktek pembuatan sabun mije. Kegiatan ini dilakukan Kelurahan Harapan Mulia, Kecamatan Kemayoran, Jakarta Pusat dengan sasaran $20 \mathrm{ibu}$ rumah tangga. Materi panduan yang disusun berupa bahan presentasi dengan PPT, leaflet dan video demonstrasi pembuatan sabun mije. Sebelum dan setelah pelatihan diukur pengetahuan dan sikap peserta terhadaap pengolah minyak jelantah menjadi sabun dengan kuesioner. Data hasil kuesioner akan dianalisis univariate untuk melihat karakteristik responden dan bivariate dengan uji t berpasanagn untuk menilai peningkatan pengetahuan dan uji Mc nemar untuk menilai perubahan sikap.

\section{HASIL DAN PEMBAHASAN}

\subsection{Pembuatan sabun dari minyak jelantah}

Pembuatan sabun dari minyak jelantah merupakan salah satu upaya untuk pemanfaatan limbah rumah tangga. Jumlah rata-rata minyak goreng yang digunakan masyarakat per minggu adalah 0,98 liter. 2. Dari hasil survey yang dilakukan ditemukan bahwa sebanyak $1.889,506$ ton minyak jelantah dibuang di selokan dan tanah di tiap minggunya (Vanessa \& Bouta, 2016)

Cara pembuatan sabun dari minyak jelantah mengikuti resep dari www.sahabatcilikalam.com. Tim membuat sabun sebulan sebelum pelatihan karena sabun hasil dari minyak jelantah idealnya bias digunakan setelah 3 minggu, sehingga pada saat pelatihan dapat ditunjukkan hasil sabun yang sudah jadi.

\subsection{Pelatihan pembuatan sabun dari minyak kelantah}

Pelatihan dilakukan di RPTRA Harapan Mulia, Kecamatan Kemayoran pada hari rabu 3 Juli 2019 kepada 20 ibu rumah tangga. Kegiatan dibuka oleh Ibu Sukarti, Kasi Kesmas Kelurahan Harapan Mulia, Kecamata Kemayoran, Jakarta Pusat. Materi diberikan melalui ceramah dengan PPT, demonstarsi dengan video, pembagian leaflet dan praktek pembuatan sabun. 


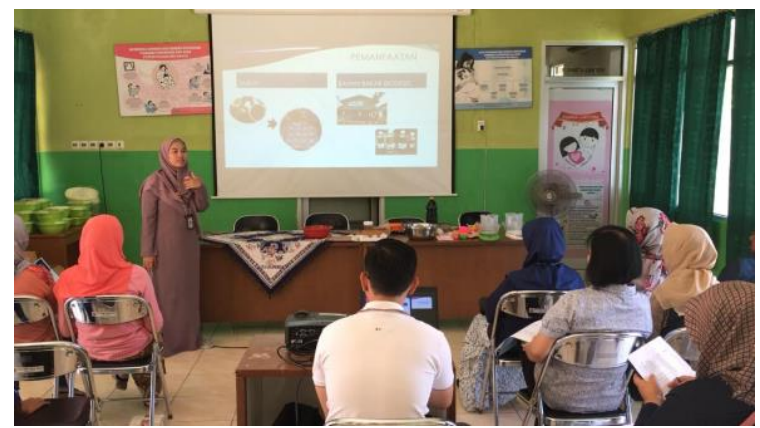

Gambar 1. Pemberian materi dengan ceramah dengan PPT.

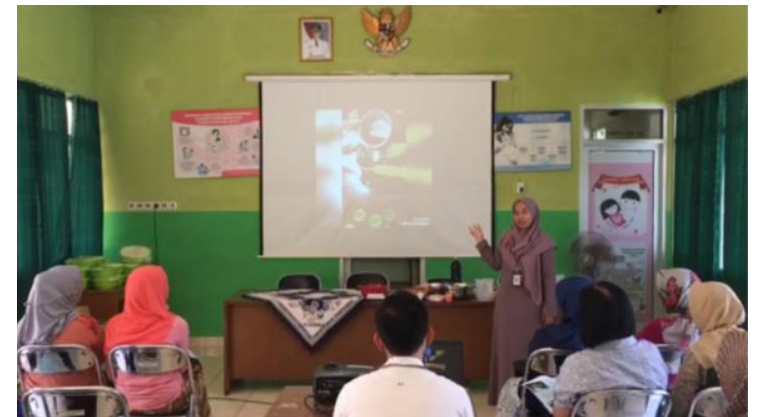

Gambar 2. Demonstrasi pembuatan sabun dari minyak jelantah dengan video.

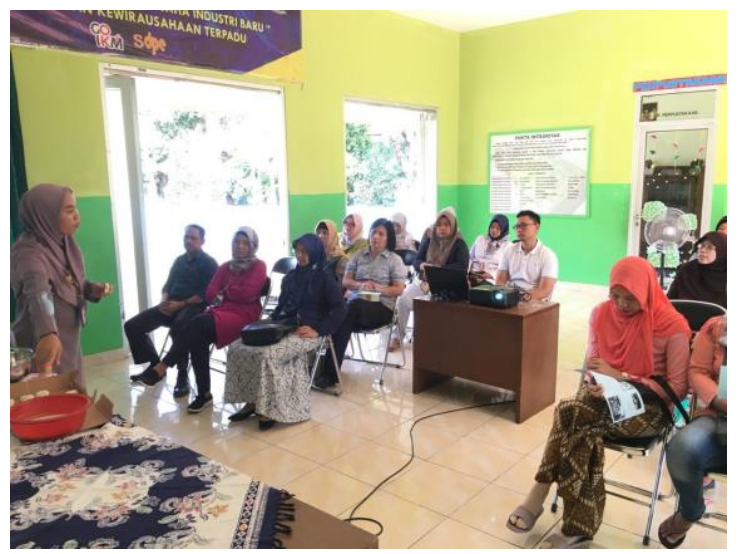

Gambar 3. Materi pembuatan sabun dari minyak jelantah dengan leaflet.

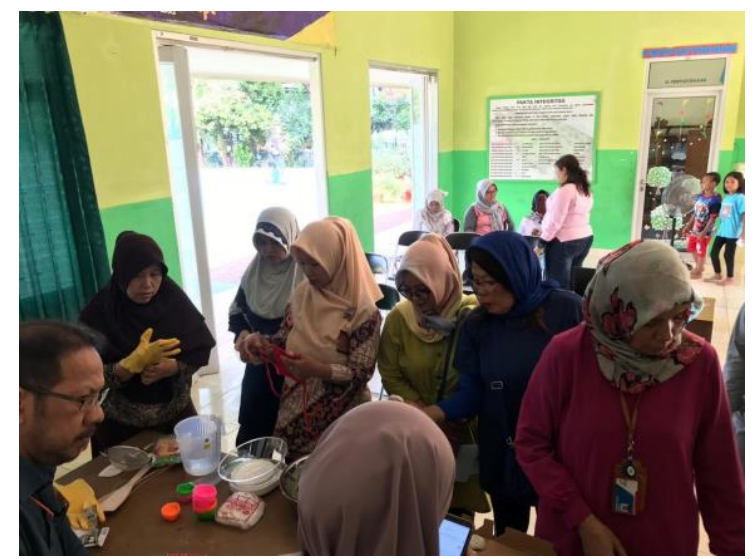

Gambar 4. Praktek pembuatan sabun dari minyak jelantah.

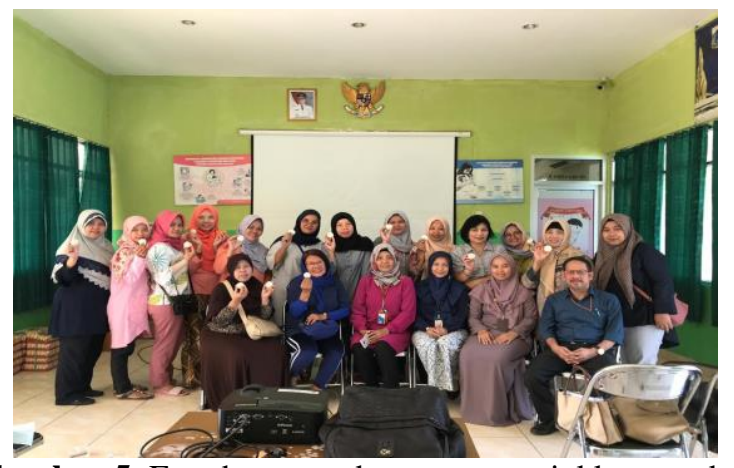

Gambar 5. Foto bersama dengan menunjukkan produk sabun.

\subsection{Karakteristik peserta}

Peserta pelatihan terdiri dari 20 ibu rumah tangga di Keluhan Harapan Mulia, Kecamatan Kemayoran.

Table 1. Karakteristik Peserta.

\begin{tabular}{|c|c|c|}
\hline Keterangan & Frekuensi (N) & Prosentase $(\%)$ \\
\hline \multicolumn{3}{|l|}{ Umur } \\
\hline 26-45 Tahun & 11 & 55 \\
\hline 46-65 Tahun & 9 & 45 \\
\hline Total & 20 & 100 \\
\hline \multicolumn{3}{|l|}{ Pendidikan } \\
\hline SMA & 14 & 70 \\
\hline Diploma & 3 & 15 \\
\hline Sarjana & 3 & 15 \\
\hline Total & 20 & 100 \\
\hline \multicolumn{3}{|l|}{ Pekerjaan } \\
\hline IRT & 16 & 80 \\
\hline PNS & 2 & 10 \\
\hline Pegawai & 2 & 10 \\
\hline Total & 20 & 100 \\
\hline
\end{tabular}

\subsection{Pengetahuan}

Pengetahuan tentang pengolah minyak jelantah menjadi sabun diukur dengan menggunakan kuesioner dengan nilai 0-100. Pengetahuan diukur sebelum dan sesudah pelatihan. Berikut adalah data hasil pengetahuan.

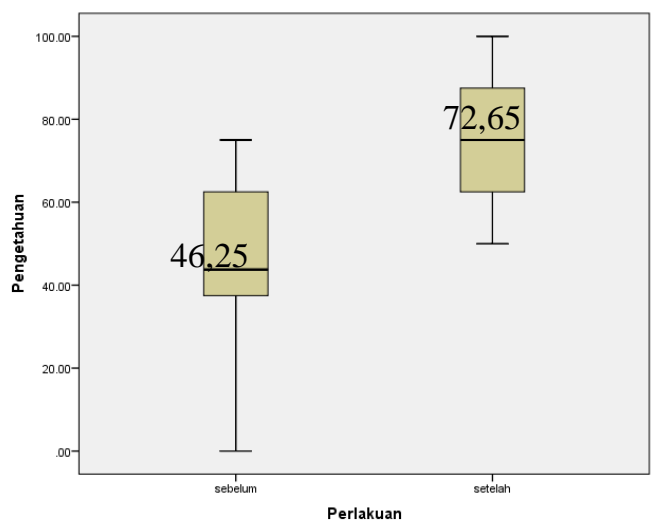

Grafik 1. Peningkatan pengetahuan tentang pengolahan minyak jelantah menjadi sabun. 
Berdasarkan grafik 1 diatas terlihat bahwa ada kenaikan nilai rata-rata dari 46,25 ke 75,62.

Peningkatan pengetahuan ini diuji dengan uji $t$ berpasangan dengan hasil seperti pada table dibawah ini:

Tabel 2. Hasil Uji t berpasangan pengetahuan sebelum dan setelah pelatihan.

\begin{tabular}{|c|c|c|c|c|c|c|c|c|}
\hline & \multicolumn{5}{|c|}{ Paired Differences } & \multirow[t]{3}{*}{$\mathbf{t}$} & \multirow{3}{*}{$\begin{array}{l}\text { d } \\
\mathbf{f}\end{array}$} & \multirow{3}{*}{$\begin{array}{l}\text { Sig } \\
\dot{(2-} \\
\text { tai } \\
\text { led } \\
)\end{array}$} \\
\hline & \multirow[t]{2}{*}{$\begin{array}{c}\text { Mea } \\
\mathbf{n}\end{array}$} & \multirow[t]{2}{*}{$\begin{array}{c}\text { Std. } \\
\text { Devi } \\
\text { atio } \\
\text { n }\end{array}$} & \multirow[t]{2}{*}{$\begin{array}{c}\text { Std } \\
\text { Err } \\
\text { or } \\
\text { Me } \\
\text { an }\end{array}$} & \multicolumn{2}{|c|}{$\begin{array}{c}95 \% \\
\text { Confidenc } \\
\text { e Interval } \\
\text { of the } \\
\text { Difference } \\
\end{array}$} & & & \\
\hline & & & & $\begin{array}{c}\text { Low } \\
\text { er }\end{array}$ & $\begin{array}{c}\text { Upp } \\
\text { er }\end{array}$ & & & \\
\hline $\begin{array}{ll}\mathrm{P} & \text { Pengetah } \\
\text { a } & \text { uanPre - } \\
\text { ir } & \text { Pengetah } \\
1 & \text { uanPost }\end{array}$ & $\begin{array}{r}29,3 \\
750 \\
0\end{array}$ & $\begin{array}{r}20,3 \\
8890\end{array}$ & $\begin{array}{r}4,5 \\
591 \\
0\end{array}$ & $\begin{array}{r}38,9 \\
173 \\
0\end{array}$ & $\begin{array}{r}19,8 \\
327 \\
0\end{array}$ & $\begin{array}{r}6, \\
44 \\
3\end{array}$ & $\begin{array}{l}1 \\
9\end{array}$ & $\begin{array}{r}, 0 \\
00\end{array}$ \\
\hline
\end{tabular}

Berdasarkan table diatas menunjukkan peningkatan pengetahuan sebelum dan setelah pelatihan pembuatan sabun dari minyak jelantah menunjukkan hasil yang significan $(\mathrm{p}=0,000)$.

\subsection{Sikap}

Sikap mengenai pengolahan minyak jelantah menjadi sabun diukur dengan menggunakan kuesioer sebelum dan setelah pelatihan, yang dikategorikan mejadi sikap positif dan sikap negative. Berikut adalah hasil pengukuran sikap sebelum dan sesudah pelatihan.

Tabel 3. Gambaran sikap peserta sebelum dan setelah pelatihan.

\begin{tabular}{lll}
\hline Sikap & $\begin{array}{l}\text { Sebelum (N/ } \\
\mathbf{\%})\end{array}$ & $\begin{array}{l}\text { Setelah (N/ } \\
\mathbf{\%})\end{array}$ \\
\hline Positif & $11(55)$ & $17(85)$ \\
Negatif & $9(45)$ & $3(15)$ \\
\hline Jumlah & $\mathbf{2 0 ( 1 0 0 )}$ & $\mathbf{2 0}$ \\
\hline
\end{tabular}

Perubahan sikap peserta setelah pelatihan adala meningkatya jumlah peserta dengan sikap positif dianalisis dengan uji Mc Nemar seperti terlihat pada table di bawah ini.

Tabel 4. Hasil uji Mc Nemar perubahan sikap sebelum dan setelah pelatihan.

\begin{tabular}{|l|l|l|l|l|}
\hline \multirow{2}{*}{$\begin{array}{l}\text { Sebelum } \\
\text { Pelatihan }\end{array}$} & \multicolumn{2}{|l|}{$\begin{array}{l}\text { Setelah } \\
\text { Pelatihan }\end{array}$} & \multirow{2}{*}{ Jumlah } & \multirow{2}{*}{} \\
\cline { 2 - 3 } & Positif & Negatif & & \\
\hline Positif & 11 & 0 & 11 & 0,031 \\
\hline Negatif & 6 & 3 & 9 & \\
\hline Jumlah & $\mathbf{1 7}$ & $\mathbf{3}$ & $\mathbf{2 0}$ & \\
\hline
\end{tabular}

Pengetahuan tentang pengolahan sabun dari minyak jelantah merupakan hal baru bagi peserta, hal ini ditunjukkan dari hasil kuesioner yang menunjukkan $100 \%$ peserta belum pernah mengetahui informasi tentang pengolahan minyak jelantah. Hal ini juga yang mendukung peningkatan pengetahuan pada 100\% peserta karena peserta sangat antusias dan secara statistic menunjukkan peningkatan yang significan. Peningkatan pengetahaun juga didukung oleh factor tingkat pendidikan peserta yang termasuk pendidikan tinggi dimana 70\% tingkat SMA, 15\% diploma dan $15 \%$ sarjana. Hal ini sesuai dengan teori Notoatmojo yang menyatakan penegtahuan di pengaruhi oleh tingkat pendidikan.

Sikap peserta terhadap pengolahan minyak jelantah menjadi sabun pada awal pelatihan menunjukkan 55\% peserta memiliki sikap positif dan $45 \%$ peserta memiliki sikap negative. Namun setelah pelatihan terjadi perubahan sikap para peserta dimana $85 \%$ peserta memiliki sikap postif sedangkan $15 \%$ peserta maasih memiliki sikap negative. Perubahan sikap setelah pelatihan juga menunjukkan perubahan yang significan secara statisti (p:0,031). Menurut Notoatmodjo (2007), sikap merupakan kesiapan atau kesediaan untuk bertindak, dan bukan merupakan pelaksana motif tertentu. Sikap belum merupakan suatu tindakan atau aktivitas, akan tetapi merupakan pre-disposisi tindakan atau perilaku. Sikap itu masih merupakan reaksi tertutup, bukan merupakan reaksi terbuka tingkah laku yang terbuka. Sikap belum merupakan suatu tindakan atau aktivitas, akan tetapi merupakan pre-disposisi tindakan atau perilaku. Hal ini sejalan dengan penelitian yang dilakukan oleh Khairunnisa (2011) yang menyatakan ada hubungan yang signifikan antara sikap dengan tindakan ibu rumah tangga dalam pengelolaan sampah domestik di lingkungan I kelurahan Pulo Brayan Darat II.

Peningkatan pengetahuan dan sikap yang secara statistic significan ini diharapkan dapat meningkat peningkatan perilaku yang baik dalam pengolahan sampah rumah tangga terutama pengolahan limbah minyak jelantah. $\mathrm{Hal}$ in sesuai dengan Notoatmodjo (2007) yang menyatakan bahwa pengetahuan atau kognitif merupakan domain yang sangat penting untuk terbentuknya tindakan seseorang. Menurut Khairunnisa (2011), jika ibu rumah tangga sebagai responden telah paham mengenai pengolahan sampah, maka hal tersebut otomatis menjadi kebutuhan, karena pada dasarnya melakukan pengolahan sampah adalah tindakan yang berdampak positif dalam banyak hal, seperti kesehatan, ekonomi dan sosial.

\section{KESIMPULAN}

Kegiatan pengabdian kepada masyarakat ini bertujuan untuk memberikan pelatihan pengolahan minyak jelantah menjadi sabun (sabun mije). Hasil dari kegiatan ini adalah adanya peningkatan pengetahuan peserta yang ditunjukkan dengan rata-rata nilai dari 46,25 sebelum pelatihan menjadi 72,65 setelah pelatihan dan uji statitik menunjukkan peningkatan ini signifikan $(\mathrm{p}=0,000)$. Selain itu juga adanya perubahan sikap yang lebih postitif tentang pengolahan minyak jelantah menjadi sabun dari $55 \%$ menjadi $85 \%$ dan uji statistic menunjukkan perubahan yang sognifikan $(\mathrm{p}=0,031)$. Perubahan ini diharapkan dapat mengubah perilaku ibu 
rumah tangga dalam pengolahan limbah minyak jelantah di Kelurahan Harapan Mulia, Kecamatan Kemayoran, Jakarta Pusat. Saran untuk kegiatan pemberdayaan masyarakat ini dapat dilanjutkan di Keluarahan dan RPTRA Harapan Mulia dengan mengembangkan produk sabun menjadi produk ekonomis.

\section{UCAPAN TERIMAKASIH}

Kegiatan pengabdian kepada masyarakat ini didanai dari Hibah Internal Lembaga Pengabdian kepada Masyarakat Universitas YARSI.

\section{DAFTAR PUSTAKA}

Alfrozi dkk. (2017). Pembuatan sabun dari limbah minyak jelantah sawit dan ekstraki daun serai dengan metode semi Pendidihan. Jurnal Ilmiah Teknik Kimia UNPAM, Vol. 1. Diakses dari http://www.openjournal.unpam.ac.id/index.php/ JITK/article/download/524/428

Khairunnisa. (2011). Hubungan karakteristik ibu rumah tangga dengan pengolahan sampah domestik dalam mewujudkan medan green and clean (mdgc) di lingkungan i kelurahan pulo brayan darat ii kecamatan medan timur kota medan tahun 2011, Diakses dari (http://repository.usu.ac.id/handle/123456 789/30773

Notoatmodjo, S. (2007). Kesehatan masyarakat ilmu \& seni. Jakarta: Rineka Cipta.

Pratiwi, P. (2014). Pembuatan sabun cuci piring cair dari minyak goreng bekas (jelantah). Laporan tugas akhir Diii. Diakses dari https://digilib.uns.ac.id/dokumen/detail/40429/P embuatan-Sabun-Cuci-Piring-Cair-DariMinyak-Goreng-Bekas-Jelantah

Undang -Undang Republik Indonesia Nomor 18 Tahun 2012 Tentang Pangan. 17 November 2012.Lembaran Negara Republik Indonesia Tahun 2012 Nomor 227. Jakarta.

Vanessa \& Bouta. (2016). Analisis jumlah minyak jelantah yang dihasilkan masyarakat di wilayah jabodetabek. Diakses dari https://www.researchgate.net

Yusnita, dkk. 2017. Food Safety Di Rumah Tangga Di Kelurahan Harapan Mulya, Kecamatan Kemayoran, Jakarta Pusat Laporan Hasil Pengabdian Kepada Masyarakat. Lembaga Laporan Hasil Pengabdian Kepada Masyarakat Universitas YARSI. Jakarta. 